\title{
Analisis Usaha Penangkaran Benih Padi (Kasus di Subak Kusamba, Desa Karangdadi, Kecamatan Dawan, Kabupaten Klungkung)
}

\author{
NYOMAN RESI ARNINGSIH, I GEDE SETIAWAN ADI PUTRA, \\ I PUTU DHARMA
}

Program Studi Agribisnis, Program Non Regular Program, Fakultas Pertanian,
Universitas Udayana. Jl. PB Sudirman Denpasar 80232
Email: nyoman.resiarningsih@yahoo.co.id
setiawanadiputra@ rocketmail.com

\begin{abstract}
Rice Seed Multification Business Analysis (A Case at Subak of Kusamba, Village of Karangdadi, Sub-District of Dawan, Regency of Klungkung)
\end{abstract}

One of supporting the success of productivity is high quality seed. Efforts to increase rice production have been done by the government. One of the government's efforts is to create programs for the achievement of food self-sufficiency of rice through the Special Effort (UPSUS), and to increase the production of rice, corn and soybeans (Pajale). The purpose of this study was to find out how much the level of income received by farmers as producers of raw materials and UD Tunas Mekar as the seed breeder of rice paddy. This research was conducted at Subak of Kusamba, Karangdadi Village, Dawan Sub-District, Klungkung Regency. The total sample was as many as 30 farmers of respondents. The analytical methods used were quantitative descriptive analysis, ratio data analysis, analysis of farming, and the $\mathrm{R} / \mathrm{C}$ ratio. The results showed that the income received by farmers as producers of raw materials of rice seeds was $R p 4.279266$ with an average land area of 3,400 square meters in one cycle of planting and the R / C Ratio obtained was 2.58. Operating revenues of paddy seed multification at UD. Tunas Mekar was Rp. 113,531,016 in one production process with the $\mathrm{R} / \mathrm{C}$ ratio of 1.50 . The suggestion that can be given that the government is expected to provide subsidized seed that can be affordable by the farmers. The cooperation between UD. Tunas Mekar and the farmers should continue to provide assistance to farmers so that they are excited about doing their farming.

Keywords: seed multiplication, rice, business analysis

\section{Pendahuluan}

\subsection{Latar belakang}

Padi merupakan tanaman pangan utama yang di konsumsi tidak kurang dari 200 juta penduduk di Idonesia. Jika konsumsi beras rata-rata 130,5kg/kapita/tahun maka total kebutuhan beras 26,1 juta ton/tahun (Wirawan, 2002). Indonesia adalah penghasil beras ketiga terbesar di dunia, tetapi masih tetap mengimpor kebutuhan berasnya dari luar negeri karena hampir $100 \%$ penduduk Indonesia mengonsumsi 
beras sebagai bahan pangan utamanya (Utama, 2015). Badan Pusat Statistik (2016) memprediksikan jika produksi padi melalui Angka Ramalan mencapai 69,87 juta ton gabah kering giling (GKG) atau mengalami penurunan dibandingkan tahun 2013 yaitu sebesar 1,98\% atau 1,41 juta ton. Tahun 2013 produksi padi sudah mencapai 71,29 juta ton GKP atau setara dengan beras konsumsi 40,08 juta ton. Penurunan produksi padi ini diperkirakan akibat dari berkurangnya luas panen padi. Produksi padi di Provinsi Bali mengalami fluktuasi dalam tujuh tahun, dari tahun 2009 s/d 2015, hal ini disebabkan adanya serangan hama, faktor cuaca dan musim tanam yang berbeda. Produksi di Provinsi Bali dalam dua tahun terahir (2014 s/d 2015) cukup tinggi yaitu 6 ton/ha dibandingkan dengan produksi nasional yang mencapai 5 ton/ha. (BPS, 2016)

Upaya peningkatan produksi padi terus dilakukan oleh pemerintah. Salah satu upaya pemerintah membuat program untuk pencapaian swasembada pangan padi melalui program Upaya Khusus (upsus) peningkatan produksi padi, jagung dan kedelai (pajale) melalui Program Perbaikan Jaringan Irigasi dan Sarana Pendukungnya. Sarana pendukung dalam program upsus peningkatan produksi tersebut meliputi Optimasi lahan, Pengembangan System of Rice Intensification (SRI), Gerakan Penerapan Pengelolaan Tanaman Terpadu (GP-PTT) padi (Ditjentan Pangan, 2016)

Lebih dari 90\% varietas unggul baru padi yang dihasilkan oleh Badan Litbang Pertanian telah mendominasi areal pertanaman padi, terutama di lahan sawah yang merupakan tulang punggung produksi padi nasional. Puslitbang Tanaman Pangan untuk pencapaian swasembada pangan harus menyiapkan teknologi dan inovasi berupa varietas unggul baru padi, jagung, kedelai, serta khusus untuk mendukung logistik dan distribusi benih unggul, akan dikembangkan model-model wilayah mandiri benih, yang komplementer dengan 1000 desa Mandiri Benih yang dikembangkan Ditjen Tanaman Pangan (BBPadi, 2015).

Penangkaran benih padi di Provinsi Bali tersebar di seluruh Kabupaten dan Kota, salah satunya adalah penangkaran benih padi UD. Tunas Mekar yang ada di Subak Kusamba, Desa Karangdadi, Kecamatan Dawan, Kabupaten Klungkung. Hal yang membedakan penangkaran benih padi yang ada di Subak Kusamba dengan Subak Delod Banjarangkan yang ada di Kabupaten Klungkung yaitu luas lahan penangkaran dan jumlah petani yang ikut dalam sistem penangkaran benih padi. Subak Kusamba dengan luas 101 ha yang terbagi menjadi empat tempek, yaitu Tempek Nengah, Tempek Uma Kutuh, Tempek Taman Sari, dan Tempek Uma Gelgel dengan jumlah petani sebanyak 175 orang. Namun tidak seluruh petani yang ikut dalam sistem penangkaran benih padi. Jumlah petani yang ikut dalam sistem penangkaran benih padi ini sebanyak 30 orang yang berada di Tempek Tempek Taman Sari. 


\subsection{Tujuan}

Tujuan dari penelitian ini adalah untuk mengetahui pendapatan petani sebagai penghasil bahan baku benih dan pendapatan usaha penangkaran benih di UD. Tunas Mekar yang ada di Subak Kusamba, Desa Karangdadi, Kecamatan Dawan, Kabupaten, Klunnglung.

\section{Metode Penelitian}

\subsection{Penentuan Lokasi Penelitian}

Penelitian ini dilakukan di Subak Kusamba, Desa Karangdadi, Kecamatan Dawan Kabupaten Klungkung. Penelitian ini dilakukan pada musim tanam bulan Mei sampai bulan Agustus 2016. Pemilihan lokasi penelitian dilakukan secara purposive sampling yaitu penetapan lokasi secara sengaja dengan suatu pertimbangan tertentu.

\subsection{Penentuan Populasi, Sampel dan Responden}

Populasi merupakan kumpulan individu atau objek penelitian yang memiliki ciri-ciri yang telah ditetapkan (Hakim, 2004). Populasi dalam penelitian ini adalah seluruh petani/anggota Subak Kusamba yang ikut dalam penangkaran benih padi, yaitu sebanyak 30 orang dengan total luas garapan 1.025 are. Sampel diambil dari populasi dengan menggunakan metode sensus yaitu keseluruhan petani baik pemilik maupun penggarap yang ikut dalam penangkaran benih padi langsung digunakan sebagai responden.

\subsection{Sumber dan Jenis Data}

Sumber data dalam penelitian ini dapat dibedakan menjadi dua yaitu data primer dan data sekunder (Sugiyono, 2016). Data primer diperoleh dari hasil wawancara dengan petani penangkar benih padi yang ada di Subak Kusamba, Desa Karangdadi, Kecamatan Dawan, Kabupaten Klungkung. Data sekunder diperoleh berbagai sumber kepustakaan. Jenis data yang digunakan dalam penelitian ini adalah data kualitatif dan kuantitatif.

\subsection{Teknik Pengumpulan Data}

Teknik pengumpulan data yang digunakan dalam penelitian ini adalah

a) Wawancara (terstruktur), yaitu tanyajawab langsung dengan responden dengan menggunakan daaftar pertanyaan yang telah disusun sebelumnya.

b) Wawancara mendalam (indepth interview), yaitu tanyajawab langsung dengan narasumber kunci dengan menggunakan pedoman wawancara.

c) Dokumentasi, yaitu pencatatan peristiwa yang sudah berlalu baik berbentuk tulisan, gambar, atau karya-karya monumental dari seseorang. 


\subsection{Analisis Data}

Sugiyono (2016) menyatakan bahwa analisis data adalah suatu proses mencari dan menyusun secara sistematis data yang diperoleh dari hasil wawancara, catatan lapangan, dan dokumentasi, dengan cara mengorganisasikan data ke dalam kategori, menjabarkan ke dalam unit-unit, melakukan sintesa, menyusun kedalam pola-pola, memilih mana yang penting dan yang akan dipelajari, dan membuat kesimpulan sehingga mudah dipahami oleh diri sendiri maupun orang lain. Penelitian ini data yang dianalisis dengan metode analaisis kuantitatif dan analisis data ratio.

Antara (2006) menyatakan bahwa analisis kuantitatif digunakan untuk menganalisis data yang bersifat bilangan atau berupa angka-angka. Analisis usaha penangkaran benih padi ini menggunakan perhitungan usahatani, R/C Ratio. Data kualitatif yang sudah terkumpul dikelompokkan sesuai dengan variabel dan keadaan yang terjadi saat penelitian. Data dianalisis melalui penafsiran data yang ada, dengan tujuan untuk mendeskripsikan secara rinci suatu fenomena sosial tertentu dengan penafsiran disertai interprestasi rasional terhadap faktor-faktor yang ada dilapangan.

\section{Hasil dan Pembahasan}

\subsection{Gambaran Umum}

Subak Kusamba secara administratif terletak di Desa Kusamba, Kecamatan Dawan, Kabupaten Klungkung. Areal Subak Kusamba dengan luas areal 101 Hektar dengan 175 orang anggota subak sebagai pemilik tanah. Subak Kusamba dibatasi oleh beberapa wilayah, yaitu sebelah utara Subak Dawan, sebelah timur Subak Singgahan, sebelah selatan Subak Badung, dan sebelah barat Selat Badung. Hasil utama dari pertanian adalah $75 \%$ dari padi dan $25 \%$ petani melakukan penanaman kedelai. Pemeliharaan ternak sapi dilakukan langsung di areal sawah dengan membuat kandang berupa pondokan kecil, untuk melindungi ternak mereka dari hujan dan terik matahari. Menurut awig-awig di Subak Kusamba, pola tanam yang dilakukan petani adalah padi - palawija. Dimana pada saat musim tanam palawija petani di Subak Kusamba menanam tanaman kedelai. Penangkaran benih padi di Subak Kusamba memiliki peranan penting untuk mensuplay kebutuhan benih padi ke subak-subak lain di Kabupaten Klungkung.

\subsection{Penerimaan}

\subsubsection{Penerimaan dan biaya usahatani penghasil bahan baku benih padi}

Penanaman benih padi memerlukan adanya benih dasar (BD) yang bisa diperoleh petani dengan cara membeli pada pekaseh Subak Kusamba dengan harga Rp. $9.000,00 / \mathrm{kg}$. Petani rata-rata menghabiskan $10 \mathrm{~kg}$ untuk lahan seluas 34 are dalam satu kali musim tanam. Hasil penelitian diperoleh rata-rata total produksi sebesar $1.486 \mathrm{~kg}$ dengan harga jual Rp. 4.700,00/kg. Jadi penerimaan yang diterima petani dari usahatani penghasil bahan baku benih padi rata-rata sebesar Rp. 6.984.200,00. 
Besarnya biaya variabel dalam usahatani penangkaran benih padi di tingkat petani dipengaruhi oleh beberapa faktor antara lain luas tanam, jumlah benih, dan teknologi yang digunakan. Biaya penelitian ini diklasifikasikan ke dalam biaya tetap dan biaya variabel. Biaya variabel meliputi benih, pupuk, obat-obatan, dan tenaga kerja. Biaya tetap dalam penelitian ini meliputi pajak tanah dan iuran subak. Biaya tetap dalam penelitian ini adalah alat-alat pertanian seperti pajak cangkul dan sabit dengan rata-rata biaya penyusutan alat-alat sebesar Rp. 24.734,00. Pajak tanah termasuk kedalam biaya tetap yang rata-ratan dikeluarkan sebesar Rp. 28.800,00. Besarnya biaya benih yang dikeluarkan petani dengan luas lahan 34 are sebesar Rp. 90.000,00. Petani penangkaran benih padi di Subak Kusamba menggunakan pestisida untuk menyemprot jenis hama walang sangit dengan rata-rata penggunaan sebanyak $340 \mathrm{ml}$ dengan harga Rp. 1.200,00/ml sehingga jumlah biaya yang dikeluarkan untuk pembelian pestisida sebesar Rp. 40.800,00. Jadi total biaya untuk pupuk anorganik, benih dan pestisida yang dikeluarkan petani selama satu kali musim tanam dalam usaha penangkaran calon benih padi adalah sebesar Rp. 418.800,00.

Ritual keagamaan merupakan bagian yang tak terpisahkan, karena dianggap penting dalam kehidupan subak. Petani melakukan kegiatan ritual keagamaan yang dilakukan sebelum menanam padi sampai menjelang panen. Sutawan (2008) ritual keagamaan di masing-masing subak tidak sama, tergantung Desa Kala Patra (tradisi adat yang dilaksanakan di daerah setempat). Upacara/ritual tingkat individual antara lain ritual ngedagin atau permulaan berupa ajengan putih kuning (nama sesaji) biaya yang dikeluarkan Rp. 3.000,00. Ritual Newasen dilakukan bertepatan dengan hari bulan purnama berupa sesaji ajengan putih kuning senilai Rp. 5.000,00. Ritual Neduh/upacara penanggulangan hama supaya tidak menyebar berupa sesaji tipat dampulan senilai Rp. 15.000,00. Ritual Biukukung dilakukan pada saat padi bunting atau sudah keluar malai yang memerlukan sesaji dengan biaya yang dikeluarkan sebesar Rp. 150.000,00. Ritual enteg sari upacara sehari sebelum panen berupa sesaji tumpeng dua tanding senilai Rp. 5.000,00. Ritual tingkat Subak/Subak Gede antara lain Mendak Toya, mebalik sumpah, merebu/mecaru, ngusaba, pekelem yang dilakasanakan setahun sekali dengan biaya yang dikeluarkan senilai Rp. 12.000,00/bit. Sedangkan odalan/upacara di Pura Subak dilaksanakan setiap 210 hari atau enam bulan menurut perhitungan kalender Bali dengan biaya yang dikeluarkan sebesar Rp. 6.000,00/bit, Ritual Ayu-ayu sebesar Rp. 10.000,00/bit. Adapun biaya yang dikeluarkan untuk ritual ngerasakin diambil dari penggoot/1uran air irigasi yang dibayar oleh krama pengoot (anggota subak yang pasif) senilai Rp. 10.000,00/bit. Ritual Nangluk merana/mencegah supaya tidak ada hama dan penyakit yang menyerang tanaman, yang dilakukan setiap Pura Subak/Ulun Suwi dengan biaya rata-rata yang dikeluarkan oleh petani sebesar Rp. 3.000,00.

Jenis aktifitas tenaga kerja yang bisa dalam penelitian ini adalah persiapan lahan, penanaman, pemupukan, penyiangan, dan panen. Biaya tenaga kerja diperoleh dengan mengalikan total curahan tenaga kerja HOK/usahatani/musim tanam dengan upah yang berlaku saat ini. Petani membutuhkan tenaga kerja untuk melakukan 
usahataninya dalam hal persiapan tanam, pemeliharaan, pemanenan sehingga kegiatan usahataninya dapat berjalan dengan baik. Jumlah tenaga kerja dalam setiap kegiatan berbeda-beda tergantung jenis kegiatannya. Persiapan lahan dilakukan secara borongan dengan biaya tenaga kerja yang dikeluarkan sebesar Rp. 612.000,00 untuk luas lahan garapan 34 are. Persemaian menggunakan tenaga kerja dalam keluarga dengan curahan tenaga kerja sebanyak 1.77 HOK. Penanaman dilakukan secara borongan dengan memperhitungkan upah tenaga kerja per hari yang berlaku di wilayah tersebut sebesar Rp. 15.000,00/are sehingga biaya penanaman yang dikeluarkan sebesar Rp. 510.000,00 untuk rata-rata luas lahan 34 are. Petani menggunakan pupuk Urea dan Ponska sesuai dengan rekomendasi masing-masing sebanyak $200 \mathrm{~kg} / \mathrm{ha}$. Luas lahan garapan sebanyak 34 are diperlukan pupuk urea dan ponska sebanyak $64 \mathrm{~kg}$. Biaya penggunaan pupuk Urea sebesar Rp. 128.000,00 dengan harga eceran Rp. 2000/kg dan biaya penggunaan pupuk Ponska sebesar Rp. $160.000,00$ dengan harga eceran $\mathrm{Rp} 2.500 .00 / \mathrm{kg}$. Pemupukan dalam penangkaran benih padi dilakukan dua kali pada padi berumur 14 dan 28 hari setelah tanam (HST). Penggunaan tenaga kerja untuk pemupukan adalah 1,71 HOK. Tenaga kerja yang digunakan untuk kegiatan pemupukan adalah tenaga kerja dalam keluarga sehingga seringkali biaya tenaga kerja ini diabaikan atau tidak dihitung dalam analisis usahatani. Penyiangan dilakukan hanya dua kali yakni pada usia padi $0 \mathrm{~s} / \mathrm{d}$ 13 hari setelah tanam (HST) dan berusia 28 hari setelah tanam (HST). Tenaga kerja yang digunakan adalah tenaga kerja dalam keluarga dengan curahan tenaga kerja sebesar 11,48 HOK. Kegiatan panen dilakukan secara borongan dengan upah per kuintalnya sebesar Rp. 60.000,00 sehingga biaya yang dikeluarkan untuk kegiatan pemanenan sebesar Rp. 891.600,00.

\subsubsection{Pendapatan}

Pendapatan merupakan selisih antara penerimaan dan total biaya usahatani secara keseluruhan (biaya riil dan biaya non riil). Besarnya pendapatan yang diperoleh responden dalam usahatani penangkaran benih padi di Subak Kusamba, Desa Karangdadi, Kecamatan Dawan, Kabupaten Klungkung adalah penerimaan dikurangi biaya-biaya keseluruhan yang dikeluarkan selama satu musim tanam sehingga memperoleh pendapatan sebesar Rp 4.279.266,00 dengan luas rata-rata 34 are dalam satu kali musim tanam. Penerimaan, biaya, dan keuntungan responden dalam melaksanakan usahatani penangkaran benih padi di Subak Kusamba pada Tempek Uma Kutuh

\subsection{Analisis Usaha Penangkaran Benih Padi di UD. Tunas Mekar}

Benih bersertifiksi merupakan benih dari suatu varietas yang telah diketahui (telah dilepas) dan diproduksi dengan sistem pengawasan serta standar sertifikasi benih, baik standar lapangan maupun laboratorium yang ketat dalam mempertahankan kemurnian varietas tersebut. Usaha produksi atau penangkaran benih bertujuan untuk menghasilkan benih sebanyak-banyaknya dengan mutu yang 
memenuhi syarat sertifikasi benih. UD. Tunas Mekar Subak Kusamba, Kecamatan Dawan, Kabupaten Klungkunga, sebagai salah satu usaha yang mengusahakan unit usaha perbenihan, adapun beberapa prosedur yang dilakukan oleh UD Tunas Mekar, untuk mendapatkan sertifikasi benih padi. (1) Permohonan sertifikasi, (2) Permohonan pemeriksaan lapang pendahuluan, (3) Permohonan pemeriksaan fase vegetative (rouging), (4) Permohonan pemeriksaan lapangan fase generatif, (5) Permohonan pemeriksaan fase menjelang panen, (6) Pengawasan pengolahan benih, (7) Permohonan pengambilan sampel benih, (8) Permohonan pengawasan pemasangan label sertifikasi.

\subsection{Penerimaan Penangkaran Benih Padi di UD. Tunas Mekar}

Penerimaan yang diterima oleh UD. Tunas Mekar dihitung berdasarkan konsep tersebut, dimana hasil produksi benih padi Ciherang adalah sebesar $37.890 \mathrm{~kg}$ dikalikan dengan harga jual benih sebesar Rp 9.000,00/kg sehingga penerimaan yang diterima oleh UD. Tunas Mekar dari hasil penjualan benih sebesa Rp. 341.010.000,00. Penangkar membeli bahan baku benih padi yang dihasilkan oleh petani yang ikut dalam sistem penangkaran benih padi di Subak Kusamba sebanyak $44.588 \mathrm{~kg}$ gabah kering panen, setelah mengalami proses penjemuran dan pembersihan mengalami penyusutan sebanyak 15\%/ton yaitu menjadi $37.890 \mathrm{~kg}$.

\subsection{Biaya Usaha Penangkaran Benih Padi di UD. Tunas Mekar}

Usaha benih sudah tentu memerlukan biaya untuk melakukan proses produksi. Adapaun biaya yang dikeluarkan oleh UD. Tunas Mekar dalam memproses calon benih sampai menjadi benih yang siap untuk dijual. Biaya tersebut termasuk barang yang dibeli dan jasa yang dibayar dalam proses produksi hingga menjadi benih siap jual. Pengajuan penangkaran UD. Tunas Mekar ke BPSB adalah kelas benih yang akan ditangkarkan, varietas yang akan di tangkarkan, dan luas lahan yang akan dijadikan penangkaran benih. Pengajuan permohonan penangkaran mengeluarkan biaya setelah surat keterangan uji lapang dinyatakan lulus dengan biaya sebesar Rp. 5.000,00/ha. Biaya pembelian Calon Benih Kelas Sebar (CBKS) dari petani penangkar dengan harga Rp. 4.700,00/kg sehingga biaya yang dikeluarkan untuk pembelian benih sebesar Rp. 209.563.600,00. Biaya pembelian karung sebanyak 40 lembar/ton sehingga biaya yang dikeluarkan sebesar Rp. 1.783.520,00. Biaya penjemuran, pembersihan, dan biaya packaging sebesar Rp. 250.000,00/ton sehingga bianya yang dikeluarkan untuk biaya tersebut sebesar Rp. 9.472.500,00. Biaya dalam proses uji laboratorium ke Badan Pengawas Sertifikasi Benih (BPSB) sebesar Rp. 7,00/kg sehingga biayanya yang dikeluarkan sebesar Rp. 240.331,00. Biaya yang dikeluarkan untuk pembuatan label adalah sebesar Rp. 60,00/lembar untuk kemasan $10 \mathrm{~kg}$ sehingga total bianya yang dikeluarkan untuk pembuatan label sebesar Rp. 205.998,00. Biaya pembuatan plastik pembungkus untuk kapasitas $10 \mathrm{~kg}$ adalah Rp. 1.500,00/lembar, sehingga biaya untuk pembuatan kemasan plastik sebesar Rp. 5.149.950,00. Biaya penyusutan peralatan blower dan mesin jahit yang dikeluarkan 
dalam satu kali proses produksi yaitu Rp. 719.444,00. Pembelian benang Rp. $6.000,00 /$ gulung, untuk 5 ton menghabiskan benang satu gulung, jadi biaya pembelian benang yang dikeluarkan sebesar Rp. 48.000,00. Membersihkan gabah menggunakan mesin blower membutuhkan bensin, untuk satu ton menghabiskan bensin satu liter, biaya yang dikeluarkan untuk pembelian bensin yaitu Rp. 244.391,00. Total biaya yang dikeluarkan oleh UD. Tunas Mekar dalam pemrosesan calon benih sampai menjadi benih adalah Rp. 227.478.984,00.

\subsection{Pendapatan yang di Terima Oleh UD. Tunas Mekar}

Pendapatan merupakan selisih antara penerimaan dan total biaya usahatani secara keseluruhan (biaya riil dan biaya non riil). Pendapatan UD. Tunas Mekar dalam pembuatan benih adalah sebesar Rp. 113,531,016,00 dengan rasio sebesar 1,50 .

\section{Penutup}

\subsection{Simpulan}

Pendapatan petani dari usahatani penghasil bahan baku benih padi sebesar Rp. 4.279.266,00 per satu kali siklus tanam dengan rata-rata luas garapan 34 are. Usahatani penghasil bahan baku benih padi di Subak Kusamba menguntungkan karena R/C ratio >1 yaitu sebesar 2,58. Pendapatan UD. Tunas Mekar sebesar Rp. 113.531,016,00 dengan R/C ratio sebesar 1,50, dalam satu kali proses produksi, untuk itu usaha penangkaran benih padi di UD. Tunas Mekar layak untuk dilanjutkan.

\subsection{Saran}

Berdasarkan hasil penelitian yang diperoleh, maka dapat dikemukakan saran sebagai berikut, diharapkan kepada instansi terkait seperti pemerintah daerah untuk memberikan benih bersubsidi sehingga harga terjangkau oleh petani agar petani berminat untuk menggunakan benih bermutu. UD. Tunas Mekar agar tetap memberikan fasilitas kepada petani seperti pupuk, benih, dan pestisida, agar kedepannya hubungan kerjasama ini tetap berjalan lancar, dan petani tidak menjual hasil calon benihnya kepada penangkar lain.

\section{Ucapan Terima Kasih}

Pada kesempatan ini penulis menyampaikan rasa terima kasih serta hormat yang sedalam-dalamnya kepada Bapak I Wayan Tanggin, selaku pekaseh Subak dan para petani anggota Subak Kusamba, Desa Karangdadi, Kecamatan Dawan, Kabupaten Klungkung.

\section{Daftar Pustaka}

Antara, M. 2006. Bahan Ajar Metodelogi penelitian Agribisnis. Program Magister Agribisnis Program Sarjana Universitas Udayana. Denpasar. 
Balai Besar Padi. 2015. Mendukung Upaya Khusus (Upsus) Peningkatan Produksi Padi, Jagung dan Kedelai untuk Mencapai Swasembada dan Kedaulatan Pangan. Diakses pada http://bbpadi.litbang.pertanian.go.id. Diunduh 3 April 2016.

BPS, 2016. Produksi Padi Nasional berdasarkan Luas Panen, Produktivitas, Produksi Gabah tahun 2009-2015. Diakses pada https://www.bps.go.id. Diunduh 26 November 2016.

BPS Prov. Bali. 2016. Jumlah Luas Panen, Rata-rata Produktivitas, dan Produksi Padi Tahun 2009-2015. Diakses pada https://bali.bps.go.id. Diunduh 26 November 2016

Ditjentan Pangan. 2016. Rapat Koordinasi Upaya Khusus (UPSUS) Padi, Jagung dan Kedelai Tahun 2016. Diakses pada http://tanamanpangan.pertanian.go.id. Diunduh 3 April 2016.

Hakim, A. 2004. Statistik Deskriptif untuk Ekonomidan Bisnis. Ekonesia. Jakarta.

Sugiyono. 2016. Metode Penelitian Kuantitatif, Kualitatif, Research dan Developement. Alfabeta. Bandung.

Sutawan. 2008. Organisasi dan Manajemen Sibak di Bali. Pustaka Bali Post. Denpasar.

Utama, M.Z.H. 2015. Budidaya Padi Pada Lahan Marginal. Kiat Meningkatkan Produksi Padi. CV. Andi Offset. Yogyakarta.

Wirawan, B. 2002. Memproduksi Benih Bersertifikat. Penebar Swadaya. Jakarta. 